\title{
The Model of Consumers' Intention to Purchase SMEs' Green Products in Indonesia: Study Case of SMEs in Makassar, South Sulawesi, Indonesia.
}

\author{
Ishak AWALUDDIN ${ }^{1 *}$, Wahyuniati HAMID², Chusnul ABADY ${ }^{3}$ \\ ${ }^{1}$ Associate Professor, Dr, Faculty of Economic and Business, Halu Oleo University Kendari, Indonesia. \\ Kampus Hijau Bumi Tridharma, Anduonohu, Kec. Kambu, Kendari City, Southeast \\ Sulawesi 93232, E-mail: ishak.awaluddin.uho@gmail.com \\ '2Lecturer, Dr, Faculty of Economic and Business, Halu Oleo University Kendari, Indonesia. \\ Kampus Hijau Bumi Tridharma, Anduonohu, Kec. Kambu, Kendari City, Southeast \\ Sulawesi 93232, Email: wahyuniati@uho.ac.id \\ ${ }^{3}$ Lecturer, Dr, Faculty of Economic and Business, Bhayangkara University Surabaya, Indonesia. \\ Ahmad Yani Frontage Road Ahmad Yani No.114, Ketintang, Kec. Gayungan, Kota Surabaya, Jawa Timur 60231 \\ Email: abadichusnul@gmail.com \\ *Corresponding Author
}

Received: 10.05.2021 Accepted: 03.08.2021 Published: 09.10.2021 DOI: $\underline{\text { 10.47750/QAS/22.184.09 }}$

\begin{abstract}
Green orientation has been main strategy for SMEs to stay competitive. However, economic landscape faced by big corporations and SMEs is rather different. Technological cues are commonly absent in SMEs' green products which highly rely on natural resources. This nature leads to low cost of production. Thus, contradict to most literature that emphasizes premium as characteristic of green products, this study considers low price as compelling attraction. SMEs commonly engineer low-tech products that heavily rely on abundant but unused resource. Low price should be a tactical strategy to embrace wide consumers. The study conceives that low price has mediating power without which SMEs' green product innovation cannot lead consumers to purchase SMEs green products. It offers three novelties according to management literature. First, its new construct SMEs' green product innovation can widen our knowledge horizon regarding green product. So far green products of SMES are still under-researched. Second, it includes new construct 'perceived price benefit' in the model of planned behavior for SMEs' green products and at the same time analyzes its mediating role between SMEs' green product innovation and consumer intention to purchase their green products. Third, another novelty is the inclusion of new construct of consumer sense of support as moderator in the relationship between SMEs' green product innovation and consumer intention to buy SMEs' green products.
\end{abstract}

Keywords: Consumer Sense of Support Intention to Buy SMEs' Green Products, Perceived Price Benefit, SMEs Green Product Innovation

\section{Introduction}

Some SMEs in Makassar have green orientation, with intention to reduce waste. SMEs ELC Lontara, for example, develops made various products from non-plastic waste. It makes bawl craft from coconut shell, straws for drinking from bamboo sticks, plates from fronds of betel palm trees, clock from wood trashes and various craft products from woven grass and

rattan

(https://palopopos.fajar.co.id/2019/08/07/pamerkan-produkramah-lingkungan/). The organizational mission is waste handling to reduce its magnitude to neutralize its negative on environment. It implements the mission by focusing on recycled products.

Another SMEs in the same sector is SMEs Adhitya. It is specialized on making products from plastic and paper wastes.
Plastic wastes commonly come from unused plastic bags, drinking bottles, instant noodle wrappers. Paper wastes can be taken from unused cardboards and old newspaper. It manipulates plastic wastes into valuable backpacks, hats, sandals, table cloths, toys, phone bags, laptop bags, plastic flowers and others. It also changes paper wastes into photo frames, tissue boxes, pencil and pen boxes and jewelry boxes. Some SMEs in Makassar also have succeeded to turn water hyacinth into valuables products such as sandal, bag, shoes and other accessories (https://www.mongabay.co.id/2013/08/27/). SMEs LaOddang Wood makes use of wood waste from unused ruins of house and building to make wall decoration products (https://www.kompasiana.com/primasari.mirati/5c0ba66aab12a e11ab082cd2/ukm-laoddang-wood-usaha-kreatif-yangmemanfaatkan-limbah-kayu-menjadi-bernilai-jual?page=all). 
SMEs under Green Creative Group with Flower indogreen brand in Makassar changes environmental waste such as old newspaper, plastic botol, plastic bag, and cardboards into household products such as flower bros, decorative lamps, bonsai and tree replica, wedding souvenir and others.

In Java, some SMEs have also focused on green sector for their products as a strategy to occupy a niche market. Konstinopel-Eco Family Shoes, for example, which bases in Western Java, embrace family and green values to mold an image. This value combination makes their products have a compelling power. Green value represents almost zero waste due to $100 \%$ handmade, and natural resources utilization. The materials could be $100 \%$ cotton, linen and coconut fibers (AJI Indonesia, 2010). In Jogjakarta, there is an SMEs that utilizes wood wastes to make home products such as accessories, necklace, and home ornaments and decoration display as a typical souvenir of Jogjakarta ((AJI Indonesia, 2010).

Greenness has been a global issue and prerequisite for entry to foreign markets. It increasingly becomes one of main priorities in the agendas of governments, business firms, and other stakeholders in many parts of the world (Gadenne et al., 2009). In Indonesia, Indonesian Ministry of Environment and Forestry through its Chief of Standardization Centre of Environment and Forestry in 2018 has emphasized that SMEs and big corporations should adopt sustainable practices in increase their competitiveness in domestic and international markets. ISO 14000 for big corporations and ISO 14005 for SMEs signal the fulfillment of environmental concerns represented in their products. In international world, ecolabeling has been imposed by 29 countries (ISWA, 2008).

Nielsen survey of 2017 to economically middle-up class respondents within 15-45 years old found that price is the biggest barrier (65 percent) in consuming green products. Only 10 percent among them considers the effects of the green products on environment. In sum, majority of Indonesia disproportionately prefers to cheap products. The mediate utility or function is a top value that consumers think important outweighing other values such as environment friendly. The survey involves 916 respondents covering several areas including Medan (162), Jakarta (301), Bali (102), Surabaya (200) and Makassar (151). It applies online method from 22nd June to 21th July, 2017 (https://www.viva.co.id/gayahidup/inspirasi-unik/957916-mahal-alasan-orang-tak-mau-beliproduk-ramah-lingkungan). Price (73 percent) is a determinant factor that influences on consumers' choice of products. It implies that buying decision in large extent is related to lower price. Environmental consideration does not much pose as a priority when it comes to product consumption. Only $10 \%$ of consumers link their consumption buying to environment concern, and most of them feel good about themselves after purchasing e-friendly products. They feel the purchase as a means to contribute to environment.

In order to find out the role of price on SMEs' eco-friendly product purchase the study explores the mediating role of perceived price benefit in the relationship between SMEs' green product innovativeness and consumer intention to buy the products. Price consideration runs contradictorily to environmental motive in product purchase. For that purpose, the research designs new construct 'consumer sense of support' to environment that conjure up happiness in purchasing green products. Since the prior survey confirms that price is more influential than environmental consideration in green product consumption, the research tends to look into mediating role of price benefit and moderating role of environment support.

\section{Theoretical Review}

\subsection{Theory of Planned Behavior}

This study builds on the framework of TPB, which posits that attitudes, subjective norms and perceived behavioral control contribute toward individuals' behavioral intentions, which in turn determines their behavior (Ajzen, 1991). Attitude refers to an individual's favorable or unfavorable assessment of performance of concerned behavior (Ajzen, 1991).

Subjective norm is a social factor that refers to perceived social pressure toward performance or non-performance of a particular behavior (Ajzen, 1991). Perceived behavioral control refers to the perceived ease or difficulty (time, money and opportunity) of performing a particular behavior and reflects past experiences and anticipated impediments (Ajzen, 1991). Intention is considered to be an immediate antecedent to behavior and is defined as an individual's readiness to perform a given behavior (Ajzen, 1991). TPB has been used widely to examine green consumer purchase intentions and behaviors (Yadav and Pathak, 2017; Chan and Lau, 2002; Liobikiene et al., 2016).

This study aims to validate the TPB in Indonesia context, especially Makassar by including several new variables, namely SMEs' green product innovation, perceived price benefit, and consumer's sense of support which are derived from theory of social exchange. SMEs' green product innovation is related to perceived support or positive action that deserves reaction. Perceived price benefit bears on benefit-cost comparison that is much cited in the theory as determining relationship or detachment. Sense of support is more associated to the willingness to give reaction or reaction upon the action of the first party.

\subsection{Theory of Social Exchange}

Theory of social exchange holds that any individual makes comparison between perceived cost and benefits as a base for relationship or transaction (Emerson, 1962). Its basic logic is that one party's action bears feedback from others. If the action is perceived positive (benefit), the others would react by doing something that should support the action indicating the willingness to make a relationship. The essence lies on the word reciprocation (Blau, 2017). The present study attempts to include the theory by representing two constructs in the models, that is perceived price benefit and consumer sense of support.

Perceived price benefit is new construct that the present study puts forward to describe Indonesian's common price sensitivity to SMEs green products. Any innovation that SMEs make by applying unused resources for production mostly not enough to attract consumers' interest. Perceived price benefit would make perceived benefits outweighs perceived cost, and this comparison would make consumers enter the transaction, or better yet strengthen relationship to SMEs by forming loyalty. It seems that perceived price benefit becomes prerequisite for SMEs' green product to be accepted widely. It does not hold true for green products equipped with high-tech innovation made by big corporations.

Sense of support refers to the willingness to express approval or support. It represents reaction or feedback to the earlier action. Consumers could express their mind through their purchasing pattern. They could approve action, vision, mission, identity, or image of an organization by their purchasing decision and otherwise. Contradicts to perceived price benefit that seems to be prerequisite for Indonesian case, that explains its mediating role in the model, sense of support only encourage consumers to purchase. It explains its 
moderating role in the model.

\subsection{Hypothesis building}

Past studies have indicated the barrier role of price for green consumption (Gleim et al., 2013; Nasir and Karakaya, 2014). Consumers tend to avoid buying green products that are more costly than other products (Blend and Van Ravenswaay, 1999; D'Souza et al., 2006). Pedro and Lemke (2013) found that many consumers discarded environmental consideration when they dealt with premium price. Choi and Parsa (2007) reported that US consumers are commonly hesitant upon higher price of green products.

Many factors affects price sensitivity attitude. It might range from types of society to demographic factors such as sex, education or age. Different societies have different attitude on price. Several studies showed that Indian consumers are concerned with price (Yadav and Pathak, 2017; Prakash and Pathak, 2017). Peattie (1992) showed that most people in developed countries make environmental issue as an important consideration in purchase decisions, implying that green awareness is also related to life sophistication Some studies pinpointed age as determining attitudes to price of green products, for example Kalantari et al. (2007) in their study of Iran consumers, and Lynn and Longhi (2011) and Longhi (2013) for UK case, emphasizing that consumers within less than 50 year old have propensity to be price sensitive to green products.

Factor of product types is under-researched. The present study intends to explore the attitude of consumers upon the SMEs products which are commonly identified as having high uniqueness and creativity but lacking technology. With this in view, it is conceived that SMEs 'green products usually have shorter life circle, and have a little impact on environment. The innovation commonly involves the application of new substitutable natural materials. The innovations itself thus only attract consumers' attention on their availability in stores but it does not necessarily translate into actual buying. Perceived price benefit complements the availability information, and significantly adds SMEs' green product attractiveness. Both operate to cognitive and affective levels that help motivate people on physic-motoric level of purchasing behavior. At this point, people could worry of regret feeling if miss the chance of not purchasing.

Drawing on abundant natural resources should result in cheaper products. The lack of skill and financial sources Indonesian SMEs commonly suffer lead to the difficulty in state-of-the-art-technology application in production process. Any products with minimum technological touch should relate to lower price compared to others equipped with technological advancement. It can be inferred that SMEs' green product innovation with low technology involvement should enable organization to offer cheaper products. In other words, SMEs' green product innovation that much relies on unused but abundantly supplied natural resources has a significant effect on perceived price benefit.

As SMEs' green product innovation is identical to lower price, the lower price of SMEs' green production innovation should become its typical attractiveness that its state-to-the-art technology-equipped counterpart commonly lack. This should serve as competitive advantage that SMEs with green products can devour. People with price sensitivity especially when it comes to green products, could turn to SMEs products. Thus, it follows that cheaper price of SMEs green products should lead to increased drive to purchase the products. In other words, the lower price of SMEs' green products thanks to its innovative process and production should have a significant effect on consumer intention to purchase SMEs' green products. To confirm these logics, the study puts forward two following hypotheses:

H1. SMEs' green product innovations have significant effects on SMEs' green product.

H2. SMEs' Green Product Innovation mediates the effect of Perceived Price Benefit on SMEs' Green Product.

H3. Perceived price benefit mediates the effect of on SMEs' Green Product.

Social exchange theory has been applied to reveal the effect of interactive relationship on support. Bagger and $\mathrm{Li}$ (2014), for example, used social exchange theory to grasp supervisors' support towards employees' families, while White and Peloza (2009) by means of the same theory attempted to explain charitable support. In green context, organization support to environmental issue could trigger consumer or staff desire to help the organization in the different forms as exchange response. One component of social exchange theory is value sharing. It holds that share value strongly motivates people to enter transaction. Altruism provides value beyond product intrinsic values consumer important for actual purchase of green products.

However, in Indonesia SMEs' green product context, the need to support among consumers could be not as high as that in advanced countries where people already high concern with environment because of better education and economic welfare. Functionality, price, social status, and hedonism are among top important aspect Indonesian's people considerations in purchasing decision. The need to support environment by purchasing green products is not determining factor even though it could encourage people to do so. It thus hypothesizes that:

H4. Sense of support moderates the effect SMEs' green product Innovation on SMEs' green product

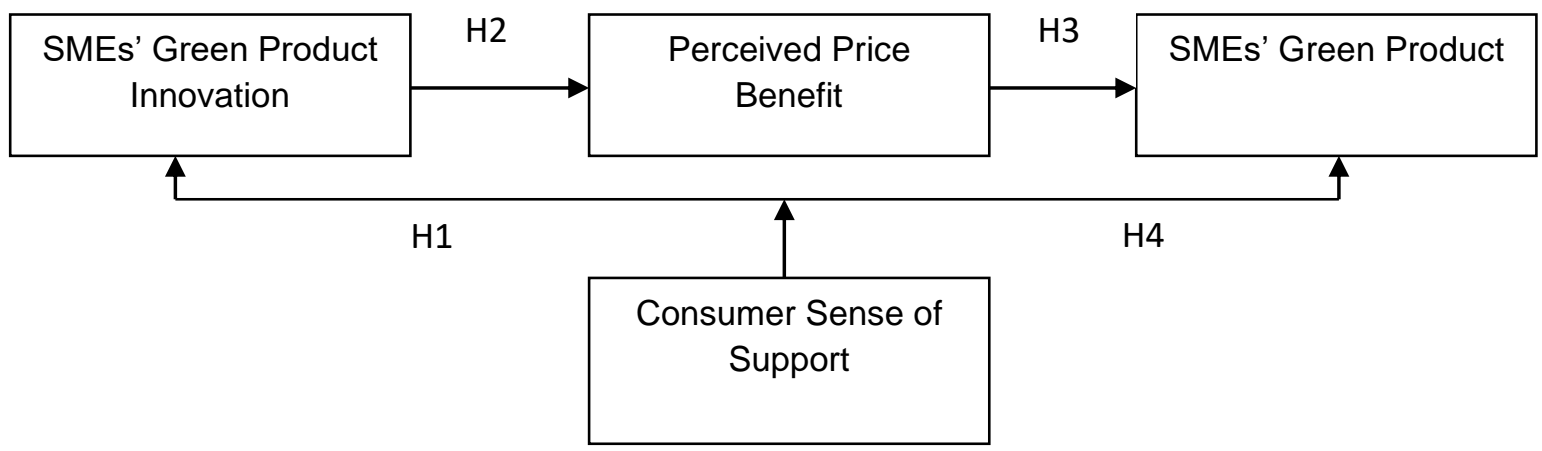

Figure 1. Research Conceptual Model 


\section{Methodology}

The research setting is some stores that sell SMEs' green products. Questionnaire is designed to accommodate green innovation including creativity in applying abundant resource as materials for new products.

Some new constructs such as SMEs' green product innovation, perceived price benefit and consumer sense of support require content and face validity tests for their novelty. Content validity involves interviews with some experts (expert judgment). While face validity requires consultation with several respondents. Kaiser-Meyer-Olkin (KMO) test is important to obtain construct validity. It will perform questionnaire distribution to 40 green SME consumers for pretest. Its sample size, based on Kahle and Malhotra (1994), is 10 times of indicators of all variables involved in the research model.

The application of SmartPLS for data analysis is quite relevant as the research model is rather complex, involving mediation and moderation analyses. As the consequence of the novelty of its three constructs, most hypothesized relationships are still predictive (Chin, 2010). Confirmatory analysis (CFA) and path analysis are important to confirm validity and reliability of researches instruments (Hair et al., 2011).

Sobel test procedure can ascertain the mediating role of perceived price benefit in the relationship between SMEs' green product innovation and SMEs' green product purchasing intention. T-test to find out t-stat values can be useful for moderation test.

\section{Results And Discussion}

The study conceives that SMEs product innovativeness in green aspect should result in reduced price as most innovations in SMEs do not involve high-technology. Uniqueness usually characterizes SMEs products, without necessary additional or new functionality that can accrue to price increase. Contradictorily, product innovations of big corporations commonly offer high value tailored to make emulation by competitors' impossible at least short terms, put in place by means of state-of-the-art technology that is hard to follow. All of these justify for increased price, and require consumers to accept premium price to have the products. Other reason is SMEs usually are driven to exploit unused waste. Some benefits are available to draw on for unused waste exploitation. First, low cost is already imperative which make production cost much cheaper. Second, the practice has the consequence of waste reduction with positive impact on environment. Perceived green support might strengthen organization positioning, differentiation, image, and even brand that all contribute to its competitive edge. However, low cost of drawing on unused waste is also subject to consumer knowledge. It raises demand on consumer side for cheaper price. It implies that product innovation initiated by SMEs by relying on tapping unused waste does not necessarily lead to higher price. Two kinds of consumer responses regarding to product innovation. The first is lower price demand that make desire to purchase is irresistible. It especially applies to aforementioned case. The second is that price is not barrier to purchase. It is usually called willingness to pay premium price, and holds when the innovation involves technology that promises future mainstream and add new functionality. Without this, innovation by SMEs should not spark attention from consumer. Their actual purchase will materialize as price does not serve as barrier. Even when it is not, the success could not run wide or in long term. Loyalty is not sustainable, as the purchase is only drawn by short curiosity. It is especially so for society with low consideration of environmental issues. Green innovation does not easily impress Indonesian consumers as green value often miss in their consideration list.

It means that in SMEs' case where innovation only involves creativity without technology, perceived price benefit somehow becomes prerequisite for actual buying. However, it does not apply universally to all products, since some circumstances also rule and need of detailed analysis. Small innovation is enough to raise curiosity, with higher demand and price as the consequences. Low awareness of environmental issue plays a part for the importance of perceived price benefit to buffer consumer interest. Even when the awareness really exists, reluctance to make a direct action could stand in the horizon. It is made possible by both the absence of significant others influence and that of media to do so. They are represented by terms social norms and perceived control in planned behavior theory. It implies that perceived price benefit accommodate both social norm and perceived control aspects. The former relates to the absence of significant others that can supply exemplary to prioritize environmental consideration in purchasing decision, while the latter relates to that of media or room to facilitate direct action in solving environmental issues. Purchasing green innovative product can be seen as a way to express concern with environment. If it is this case, then we can say that perceived price benefit serves as full mediation in relationship between SMEs' green product innovativeness and intention to buy SMEs' green products. Consumer sense of support represents perceived control in planned behavior theory and could moderate relationship between SMEs' green product innovativeness and intention to buy SMEs' green products.

As regards to moderating role of SMEs' green product innovation, it itself carries the message of organization's concern with environmental issues and support to make some improvements. The measures to take account of environmental issues are partly the result of consumer pressure. Many people are increasingly aware of environmental issue urgency and put it into their purchasing decision, as they also know that businesses contribute to environmental issues in the form of pollution and waste. They would appreciate if businesses attempt to make some adjustments in the way they produce that sustains ecosystem. They could express this appreciation and gratitude by willingness to give the same support to ecosystem. They could consider the behavior of buying e-products as representing their support to any effort of ecosystem improvement. This logic lends support from social exchange theory that emphasis on equal response to another party's action as a signal of approval and support to other deed. If it is the case, medium or opportunity to express what they think or feel become critical, and it in economic term is a need. Education and age play significant part on personal awareness of environmental issues. Individuals with high personal awareness easily alert to environment-related events such as oil spill or forest burning, and the drive to purchase green products could derive from personal norm. In globalization era, where individuals commonly make purchasing decisions based on others' references through social media, other people's opinions are equally influential.

\subsection{Limitations and Future Research}

The present study only focuses on one model. Comparison between different models of the same variable is important to find which the fit is. Analysis of direct effect of consumer sense 
of support on purchasing intention is equally challenging, putting it as mediating variable in the relationship between SMEs' Green product Innovation and Intention to buy SMEs' Green products.

Research that performs this analysis should take into account on demographical aspects that enable for mediating role of sense of support. Deep analysis on when and where this mediating or even only moderating role of sense of support is significant is essential for richer knowledge in green area. In today context, the common logic is that the mediating role could be the case for some consumers in certain advanced countries. While, moderating role for probably some consumers in certain developing countries. However, it should be proven by sound research to confirm what factors that makes moderating or mediating roles significant.

In other to explore planned behavior more fully, future research also could insert consumer actual buying behavior in the model along with consumer sense of support. Comparison of models between consumers of SMEs and those of big companies are also compelling.

\section{Conclusions}

The study proves that the model that inserts social exchange theory into planned behavior theory's model is useful to grasp Indonesian consumers' attitude toward SMEs' green product innovation. The new constructs - perceived price benefit and sense of support - are derived from social exchange theory. Perceived price benefit would make perceived benefit outweigh perceived cost, and justify the purchase. Its absence would make any SMEs green innovation in their products is not interesting and do not attract consumer attention. They would think that the hurry to purchase is not important, and waiting for better products is worth instead. In that case, perceived price benefit plays a full mediation between SMEs' green product innovation and intention to buy SMEs' green products. It means that any innovation in SMEs green products does not necessarily lead to consumer intention to buy their green products. SMEs' entrepreneurs should concern with price when they plan to launch new green products.

The need to support is not priority in Indonesian consumer priority scale. Functionality is the first consideration as a base to purchase. It is followed by price, reliability and efficiency. The need to support only encourages people to purchase but not enough to urge them to do so. It explains the expected result of significant moderating role of consumer sense of support in the relationship between SMEs' green product innovation and consumer intention to buy their green products.

\section{References}

[1] AJI Indonesia. (2010). Si Kecil Ramah Lingkungan: Kumpulan Liputan UMKM Ramah Lingkungan.

[2] Ajzen, I. (1991). The theory of planned behavior Organizational Behavior and Human Decision Processes, 50(2), 179-211. doi:10.1016/0749-5978(91)90020-t

[3] Bagger, J., \& Li, A. (2011). How Does Supervisory Family Support Influence Employees' Attitudes and Behaviors? A Social Exchange Perspective. Journal of Management, 40(4), 1123-1150. doi:10.1177/0149206311413922

[4] Blau, P. M. (2017). Exchange and Power in Social Life. 1-352, doi:10.4324/9780203792643
[5] Blend, J. R., \& Ravenswaay, E. O. (1999). Measuring Consumer Demand for Ecolabeled Apples. American Journal of Agricultural Economics, 81(5), 1072-1077. doi:10.2307/1244086

[6] Chan, R. Y. K., \& Lau, L. B. Y. (2002). Explaining Green Purchasing Behavior. Journal of International Consumer Marketing, 14(2-3), 9-40. doi:10.1300/j046v14n02_02.

[7] Choi, G., \& Parsa, H. G. (2006). Green Practices II. Journal of Foodservice Business Research, 9(4), 41-63. doi:10.1300/j369v09n04_04

[8] D'Souza, C., Taghian, M., Lamb, P., \& Peretiatkos, R. (2006). Green products and corporate strategy: an empirical investigation. Society and Business Review, 1(2), 144-157. doi:10.1108/17465680610669825

[9] Emerson, R. M. (1962). Power-Dependence Relations. American Sociological Review, 27(1), 31. doi:10.2307/2089716

[10] Gadenne, D. L., Kennedy, J., \& McKeiver, C. (2008). An Empirical Study of Environmental Awareness and Practices in SMEs. Journal of Business Ethics, 84(1), 45-63. doi:10.1007/s10551-008-9672-9

[11] Gleim, M. R., Smith, J. S., Andrews, D., \& Cronin, J. J. (2013). Against the Green: A Multi-method Examination of the Barriers to Green Consumption. Journal of Retailing, 89(1), 44-61. doi:10.1016/j.jretai.2012.10.001

[12] Hair, J. F., Ringle, C. M., \& Sarstedt, M. (2011). PLS-SEM: Indeed a Silver Bullet. Journal of Marketing Theory and Practice, 19(2), 139-152. doi:10.2753/mtp1069-6679190202

[13] Kahle, L. R., \& Malhotra, N. K. (1994). Marketing Research: An Applied Orientation. Journal of Marketing Research, 31(1), 137. doi:10.2307/3151953

[14] Liobikienè, G., Mandravickaitè, J., \& Bernatonienè, J. (2016). Theory of planned behavior approach to understand the green purchasing behavior in the EU: A cross-cultural study. Ecological Economics, 125, 38-46. doi:10.1016/j.ecolecon.2016.02.008

[15] Longhi, S. (2013). Individual pro-environmental behaviour in the household context. ISER Working Paper Series. Essex.

[16] Luzio, J. P. P., \& Lemke, F. (2013). Exploring green consumers' product demands and consumption processes: The case of Portuguese green consumers. European Business Review, 25(3), 281-300. doi: 10.1108/09555341311314825.

[17] Lynn, P., \& Longhi, S. (2011). Environmental attitudes and behaviour: who cares about climate change? Understanding Society. Retrieved from https://www.understandingsociety.ac.uk/system/uploads/assets /000/000/023/original/Understanding-Society-EarlyFindings.pdf?1355226993\#page $=109$.

[18] Aslihan Nasir, V., \& Karakaya, F. (2014). Consumer segments in organic foods market. Journal of Consumer Marketing, 31(4), 263-277. doi:10.1108/jcm-01-2014-0845

[19] Peattie, K. (2001). Golden goose or wild goose? The hunt for the green consumer. Business Strategy and the Environment, 10(4), 187-199. doi:10.1002/bse.292

[20] White, K., \& Peloza, J. (2009). Self-Benefit versus OtherBenefit Marketing Appeals: Their Effectiveness in Generating Charitable Support. Journal of Marketing, 73(4), 109-124. doi:10.1509/jmkg.73.4.109

[21] Chin, W. W. (2009). How to Write Up and Report PLS Analyses. Handbook of Partial Least Squares, 655-690. doi:10.1007/978-3-540-32827-8_29

[22] Yadav, R., \& Pathak, G. S. (2017). Determinants of Consumers' Green Purchase Behavior in a Developing Nation: Applying and Extending the Theory of Planned Behavior. Ecological Economics, 134, 114-122, doi: 10.1016/j.ecolecon.2016.12.019 